
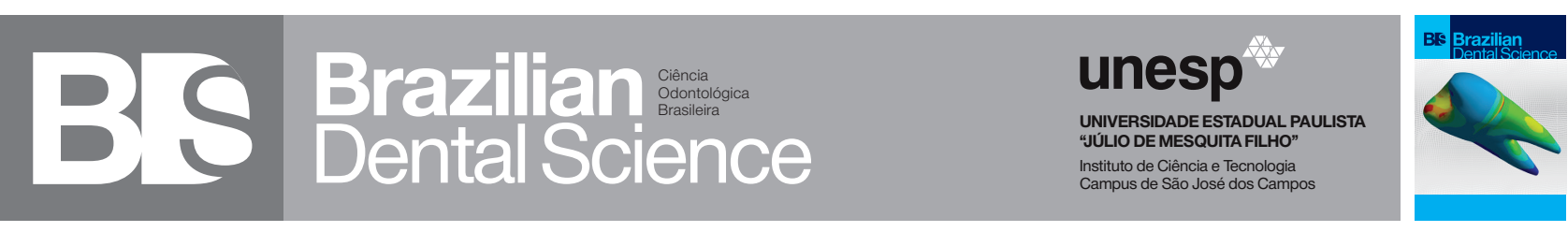

\title{
Influence of the occlusal contacts in formation of Abfraction Lesions in the upper premolar
}

\author{
Influência dos contatos oclusais na formação de lesões de Abfração no pré-molar superior
}

Victória Luswarghi Souza COSTA ${ }^{1}$, João Paulo Mendes TRIBST ${ }^{2}$, Alexandre Luiz Souto BORGES ${ }^{2}$

1 - São Paulo State University (Unesp) - Institute of Science and Technology - São José dos Campos - SP - Brazil.

2 - São Paulo State University (Unesp) - Institute of Science and Technology - São José dos Campos - Department of Dental Materials and Prosthodontics - SP - Brazil.

\begin{abstract}
Objective: The aim of this study was to observe the influence of different occlusal contacts in a superior pre-molar structure using Finite Element Analysis. Material and Methods: A three-dimensional model of a superior pre-molar was designed to simulate three occlusion situations, namely central occlusion and two types of lateral occlusion contacts. The model presents enamel, dentin, a periodontal ligament and a fixation cylinder separately. All materials were considered isotropic, linear and homogeneous, and the contacts of each structure were perfectly bonded. On analysis software, a load was applied to an occlusal surface at $40^{\circ}$ to the long axis on lateral contacts, and directed to the long axis on central occlusion contact. Results: The results were obtained in stress maps and the maximum values were then plotted in table for quantitative comparison, with the enamel concentrating more stress than dentin and the occlusal contact presenting the worst biomechanical behavior. Conclusion: Within the limitations of this study, it is possible conclude that: eccentric contacts have higher potential to develop abfraction lesions on the cervical region of teeth, thus increasing the magnitude of tensile and shear stresses.
\end{abstract}

\section{KEYWORDS}

Finite Elements Analysis, Abfraction; Stress distribution; Occlusion, Premolar.

\section{RESUMO}

Objetivo: observar a influência de diferentes contatos oclusais em uma estrutura pré-molar superior usando a análise por elementos finitos. Material e Métodos: um modelo tridimensional de pré-molar superior foi projetado para simular três situações de oclusão: oclusão central e dois tipos de contatos de oclusão lateral. $\mathrm{O}$ modelo apresentou esmalte, dentina, ligamento periodontal e um cilindro de fixação separadamente. Todos os materiais foram considerados isotrópicos, lineares e homogêneos, e os contatos de cada estrutura foram considerados perfeitamente ligados. No software de análise, aplicou-se uma carga na superfície oclusal a $40^{\circ}$, ao longo eixo do dente, nos contatos laterais e direcionada para apical no contato de oclusão central. Resultados: os resultados foram obtidos nos mapas de tensão e os valores máximos foram escritos em tabela para comparação quantitativa, com o esmalte concentrando mais tensão do que a dentina e o contato em cúspide de balanceio apresentando o pior comportamento biomecânico. Conclusão: dentro das limitações deste estudo, é possível concluir que: os contatos excêntricos facilitam o surgimento de lesões de abfração na região cervical dos dentes, pois aumentam a magnitude das tensões de tração e de cisalhamento.

\section{PALAVRAS-CHAVE}

Análise por Elementos Finitos, Abfração; Distribuição de Tensão; Oclusão, Pré-molar. 


\section{INTRODUCTION}

$\mathrm{N}$ on-Carious Cervical Lesions (NCCL) is a class of tooth lesion that is not formed by the demineralizing action of cariogenic bacteria. This class of lesions includes Erosion, Abrasion, Attrition and Abfraction, capable of causing clinically visible loss of hard tissue over time in areas which are not usually compromised by cariogenic plaque [1].

Regarding form, these lesions may be wedge, disc, flattened or irregular shaped, varying in stress and depth [2]. The facial surfaces are usually the most committed, rarely being seen on lingual and proximal surfaces [3].

Abfraction lesions are influenced by occlusal loads, thus experiencing enamel and dentine fatigue due to structural flexure on a location away from the area where the load is being applied [4]. Clinically, a wedge shaped lesion can mainly be seen on the cervical region [2]. This term includes a series of lesions that compromise the subgingival area, where teeth surfaces have no contact with acids, other teeth or mechanical factors (as occurs in other NCCL) [5]. This also applies for cases in which the lesion only compromises a single tooth [6].

Regarding the etiology, past studies correlate occlusal and cervical loss of tissue in which more than $80 \%$ of the tooth affected by cervical lesions presents occlusal wear [7].It has also been observed that occlusal and cervical wear stress grew proportionally during a 14-year study [8]. Concerning the direction of the loads, it is known that loading dissipates more evenly over enamel and dentin when directed to the long axis; in contrast, lateral loading promotes structural flexure, and when occurring cyclically causes weakening and rupture of the bond between hydroxyapatite crystals [7]. Abfraction lesions are most seen in premolars, in both maxilla and the jaw [9].

Finite Element Analysis (FEA) is a well- explored tool in dentistry which can simulate teeth and other natural tissues [10], as well as restored teeth [10], prostheses [11] and dental implants [12].

Previous studies have already evaluated the behavior of dental elements under several types of loadings using finite element analysis, in favor of analyzing the occurrence of abfraction lesions in premolars over two-dimension analysis $[13,14]$. When simulated loadings are analyzed over three-dimensions, they have mainly aimed to evaluate the centric and malocclusion contacts [15]. The present study aims to compare dental structure behavior under centric loadings and in lateral loadings with balance contact and group function contacts which are physiologically observed in the mouth.

Therefore, this work uses Finite Element Analysis with the aim of observing the stress distribution that occurs on the teeth over three types of occlusal loading - centric contact, working contact and balancing contact - to be compared from the biomechanical point of view in attempt to verify the contacts with greater potential to generate Non-Carious Cervical Lesions, which are increasingly being observed in day-to-day clinics.

\section{MATERIAL AND METHODS}

\section{Finite Element Analysis (FEA)}

A previously validated human first premolar [16] was selected for this study. The file was accessed by CAD software in STL format (Rhinoceros 5.0 McNeel North America, USA) and anatomic lines were drawn based on the Biocad method [17]. After delimitation, the lines were smoothened and split so that the surfaces could be created [2]. Every single surface was modeled using three or four anatomic lines until obtaining a volumetric solid of every individual structure.

The modeled dental structure included enamel, dentin, the pulp chamber and a 
periodontal ligament. A fixation cylinder was used to contain the teeth and simulate the bone tissue using material validated for laboratorial analysis (Figure 1).

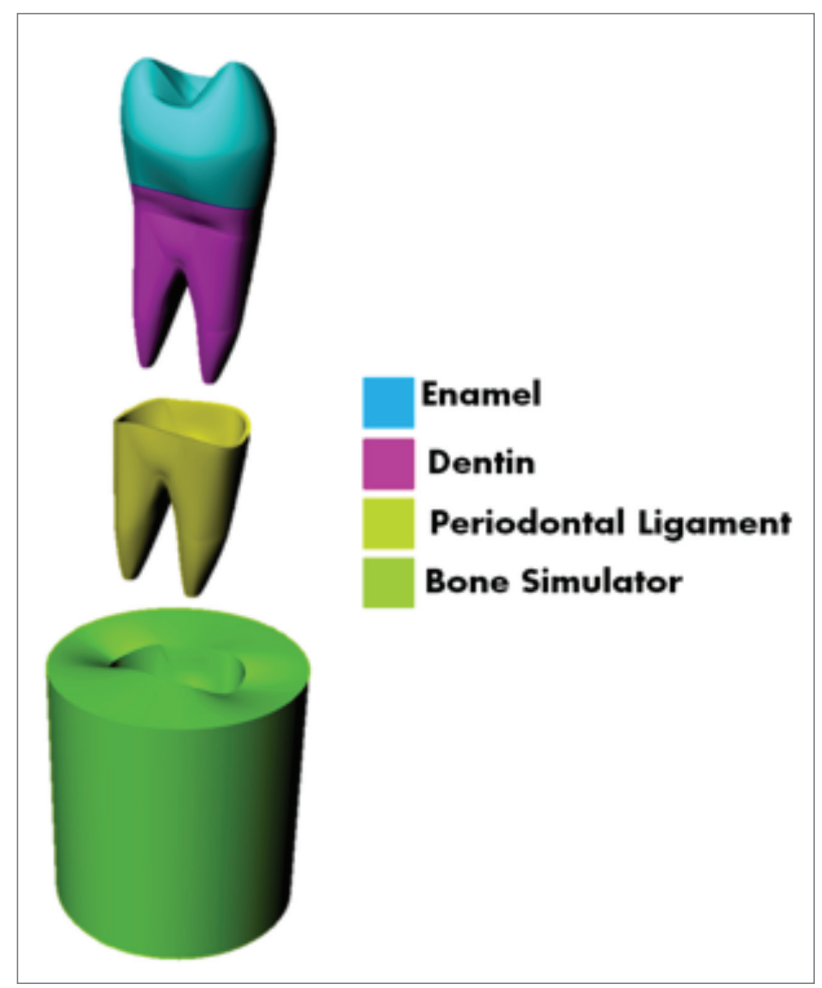

Figure 1 - 3D geometry created in computer aided design software

After modeling, the solids were imported to analysis software (ANSYS 15.0, ANSYS Inc., Houston, TX, USA) and the contacts which were considered perfectly bonded between all the structures and the system were closed on the cylinder base. The meshes were generated through tetrahedral elements and a convergence test $(10 \%)$ determined the number of nodes (126980) and elements (72460) in the model. The mechanical properties of each figure were obtained through the literature (Table I) [18-20] and inserted in the software for static structural analysis. Different axial loadings were simulated to perform the situation proposed for this study: central occlusion (directed to the long axis of the tooth), laterality on the work cusp (at $40^{\circ}$ ), and interference contact to balance movement on the facial cusp (at $40^{\circ}$ ) (Figure 2).

The selected analysis criterion was the maximum principal stress and maximum shear stress on dentin and enamel, aiming to evidence the future failing areas after applying the loadings. Regarding the periodontal ligament, the analysis criterion was the equivalent strain as this structure does not fracture. Each of the dental element geometries were analyzed in colorimetric scale for qualitative comparison of each of the simulated occlusion situations. The peak stress values were then plotted on a table.

Table I - Mechanical properties of the materials used in the analysis

\begin{tabular}{|cccc|}
\hline Material & $\begin{array}{c}\text { Elastic } \\
\text { Modulus (GPa) }\end{array}$ & $\begin{array}{c}\text { Poisson } \\
\text { coeficient }\end{array}$ & Reference \\
\hline Enamel & 84 & 0.30 & Versluis etal. \\
\hline Dentin & 18 & 0.23 & Versluis etal. \\
\hline $\begin{array}{c}\text { Periodontal } \\
\text { Ligament }\end{array}$ & $1.18 \times 10^{-5}$ & 0.45 & Rundguist et al. \\
\hline $\begin{array}{c}\text { Polyurethane } \\
\text { Pona }\end{array}$ & 3.6 & 0.3 & Souza et al. \\
\hline
\end{tabular}

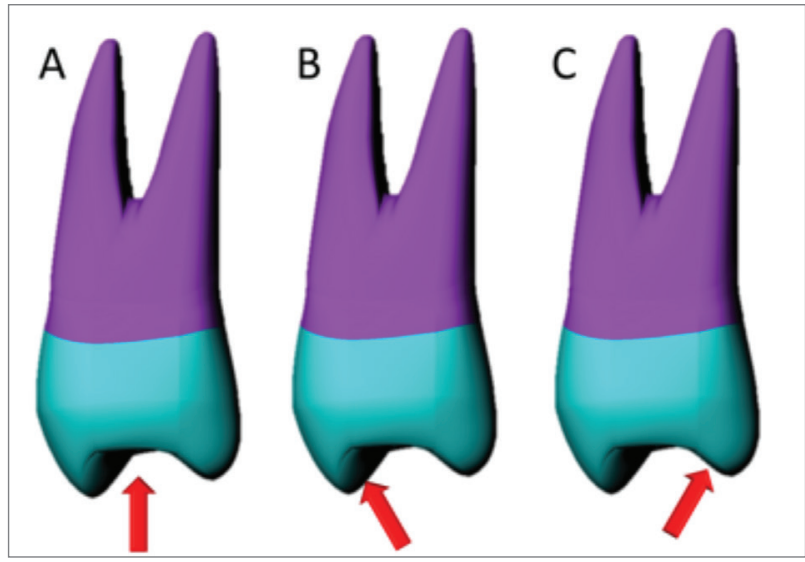

Figure 2 - Simulated occlusal contacts on: A) centric occlusion, B) working contact and C) balancing contact

\section{RESULTS}

The colorimetric graph shows the stress distribution focusing on the tensile areas on the dental element during all the loadings. Stress distribution was the most homogeneous during 
the central occlusion position on all the dental element's faces (Figure 4) when compared to the other simulated positions. There were more higher stress concentration areas on the cementenamel junction region on the cervical portion for both work and balance lateral contact positions, thus suggesting a greater probability of problems in those areas. The main difference between the two eccentric simulated movements was that the stress was concentrated on the opposite side of the loading cusp - therefore, the contact on the work surface generated stress on the facial surface, and the contact on the balance cusp generated stress on the buccal surface.

\section{DISCUSSION}

Previous researches have studied the type of loading as to the stress promoted on the dental element $[13,15]$. It is a consensus that centric loadings are best absorbed by the dental structure, not only generating less stress but being distributed more evenly along the tooth. Furthermore, the centric contacts do not produce considerable structural flexure - they only promote compressive stress, against which the dental element presents high resistance when its mineralized structures are intact.

Using the central contacts as a parameter, the loadings on work and balance cusps are more harmful for teeth. Under lateral loading, it was demonstrated that the generated stress is of greater magnitude, being distributed in a more harmful way over the structure, and mainly concentrating on cervical areas to the point of breaking the chemical bonding between the enamel prisms [21,22]. The results of this paper demonstrated that the balance contact is more willing to cause cervical losses, followed by the work cusp occlusal contact, and lastly the most even situation is the maximum intercuspation position (Figure 3-5). These results corroborate with previously studies [15] which verified greater stress values in the superior premolar when malocclusion problems were present.

As considered in the literature, [13,14] the surface that anatomically presented smaller quantities of enamel suffer stress concentration to a greater degree; these studies showed higher stress concentration on the cervical region of the inferior premolar's facial surface when the loadings were applied on the lingual cusp. The same is verified in the present study on the cervical region of the superior premolar's facial surface when oblique loadings are applied to the palatal cusp (Figure $3,4)$. The simulated contacts in this present study are the most harmful for the dental structure, those being the lateral contacts that occur in the internal slopes of the cusps (Figure 5). Moreover, the previously studies $[13,14]$ shows very similar values observed in loadings on both facial and lingual cusps. In this study, it was shown that the higher concentrations were found on facial enamel for balance contacts; a fact which justifies the highest occurrence of cervical lesions on facial surfaces as clinically observed.

The stress found in our study results are based on the theory of abfraction by overload. This theory defines that the cusps are submitted to axial compression loading during tooth structural flexure, thus resulting in cervical stress similar to a diametric compression application. This then results in degradation of the links between hydroxyapatite crystals, which leads to crack formation and eventually results in enamel loss on these areas $[14,23]$. 


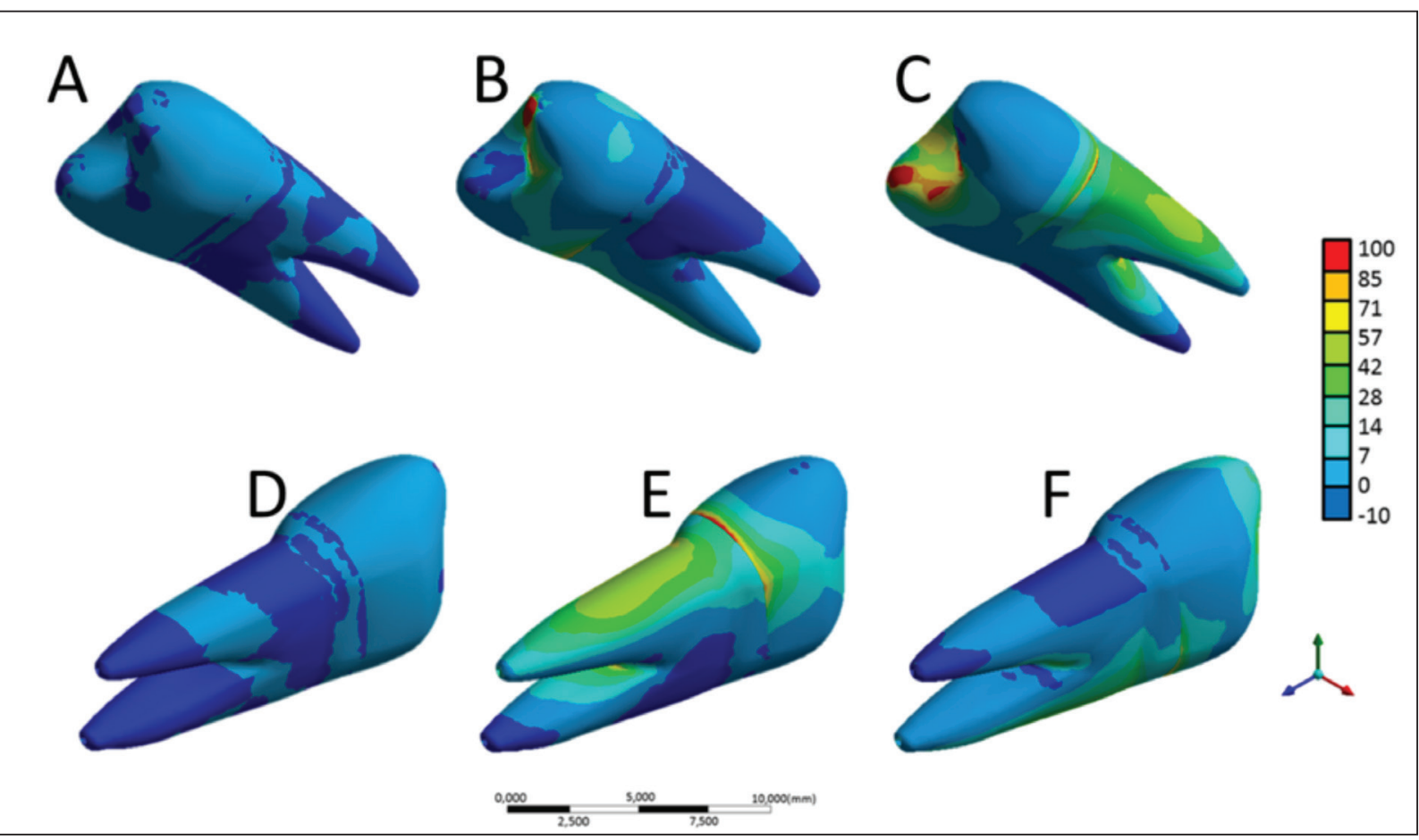

Figure 3 - Maximum principal stress in premolar during contact: A) on central occlusion, buccal perspective; B) on work cusp, buccal perspective; C) on work cusp, buccal perspective; D) on central occlusion, palatal perspective; E) on balance cusp, palatal perspective; F) on balance cusp, palatal perspective

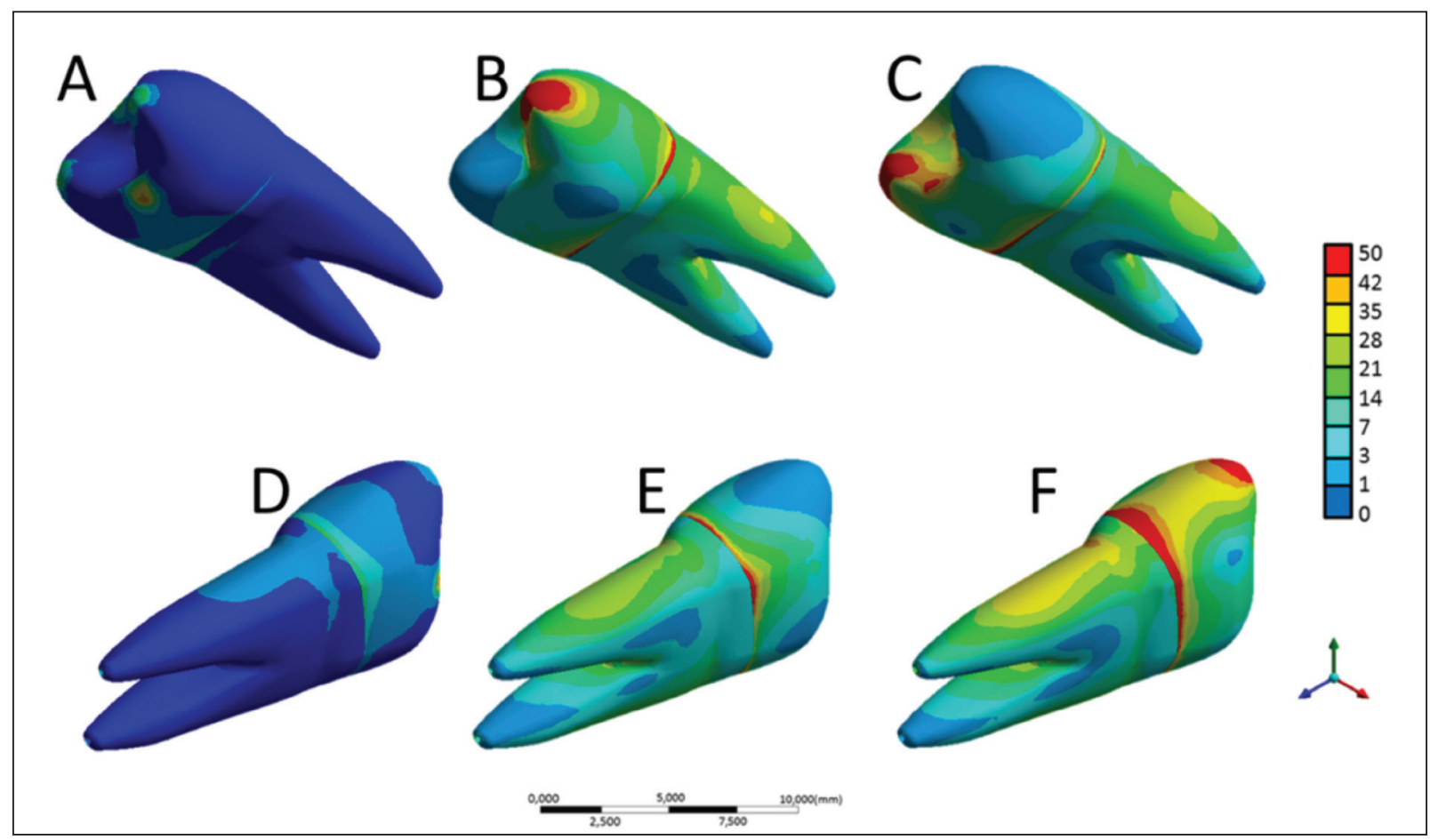

Figure 4 - Maximum shear stress in premolar during contact: A) on central occlusion, buccal perspective; B) on work cusp, buccal perspective; C) on work cusp, buccal perspective; D) on central occlusion, palatal perspective; E) on balance cusp, palatal perspective; F) on balance cusp, palatal perspective 
The stress concentrates in a higher magnitude on the cervical area on the opposite surface when loadings are applied to a premolar cusp, and more specifically tensile stress; with the tensile being (as known) more harmful for the dental enamel than shear (Table II). These results were supported by literature relates with similar condition [18-21]. This is contrary to the studies of Spears et al. [25] which shows the opposite when applying loadings over a premolar lingual cusp, resulting in stress concentrations on the cervical area of the lingual aspect itself, probably because the author has used different stress criteria.

The prevalence of class $\mathrm{V}$ lesions is more common in inferior premolars when compared to superior ones [26]. Some authors state that the higher moisture content being associated with lingual orientation of the inferior tooth makes them more susceptible to fail under tensile forces [21,25,27]. However, this work shows that, when the loading occurs on a larger cusp (facial), higher tensile stress values are found on the cervical region, but this loading is uncommon in the superior tooth and would only happen in unusual circumstances. Thus, based on our studies we can suggest that the lower prevalence of class $\mathrm{V}$ lesions on superior premolars also occurs because of the work cusp being palatal.

Table I - Tensile and shear stresses peaks according to the load and local of concentration

\begin{tabular}{|c|c|c|c|}
\hline Load Type & Local & $\begin{array}{l}\text { Tensile Stress } \\
(\mathrm{MPa})\end{array}$ & $\begin{array}{l}\text { Shear Stress } \\
(\mathrm{MPa})\end{array}$ \\
\hline \multirow{4}{*}{$\begin{array}{l}\text { Centric } \\
\text { Occlusion }\end{array}$} & Buccal Dentin & 0.53 & 1.1 \\
\hline & Palatal Dentin & 0.37 & 6.8 \\
\hline & Buccal Enamel & 1.09 & 5.4 \\
\hline & Palatal Enamel & 1.34 & 20.1 \\
\hline \multirow{4}{*}{$\begin{array}{l}\text { Working } \\
\text { Contact }\end{array}$} & Buccal Dentin & 5.02 & 24.1 \\
\hline & Palatal Dentin & 36.44 & 17.3 \\
\hline & Buccal Enamel & 2.15 & 60.4 \\
\hline & Palatal Enamel & 79.46 & 30.5 \\
\hline \multirow{4}{*}{$\begin{array}{c}\text { Balancing } \\
\text { Contact }\end{array}$} & Buccal Dentin & 40.68 & 17.2 \\
\hline & Palatal Dentin & 6.64 & 31.2 \\
\hline & Buccal Enamel & 100.85 & 49.3 \\
\hline & Palatal Enamel & 4.09 & 105.1 \\
\hline
\end{tabular}

One other structure analyzed in our study is the periodontal ligament, as the Finite Element Method is accepted to analyze the problems related to dental movement, especially when the displacement force distribution is being studied [28]. As such, the required results were in equivalent deformation and not stress, because the fracture of this structure does not occur in the mouth. By analyzing what we have found, it may be observed that functional maxillary positions (work and central relation) generate more and less deformation, respectively, than a less common situation (balance contacts), which allows us to suppose that any unusual contact would not generate damage to the periodontal ligament (Figure 6). This situation is hypothetical and based on theoretical results of a linearly elastic and homogeneous isotropic model, which is a limitation. Therefore, our results show that the masticatory load can facilitate the emergence of cervical lesions, especially when the contact occurs on the balance cusp, and that this contact may not be capable of sensitizing the periodontal ligament as much as a physiological work contact. This may also be one of the reasons why cervical lesions are more common in older patients [29], because more harmful contact in the long run and without being uncomfortable, could be responsible for cervical enamel loss. The prevention or reduction of the magnitude of generated tensile stresses in the dental element can be achieved by adjustment of the occlusal contacts [10]. The present study results shows that, when a constant loading is applied over a magnified area, the resultant of forces orientation tend to the long axis of the tooth and the generated stresses are better distributed over the tooth structure and periodontal ligament. These findings suggest that the adjustment should be made in a way of achieving best exploitation of the occlusal area of the dental crown, by distributing the occlusal contact points.

Concerning biting force, higher magnitude masticatory forces do not coincide with the 
perpendicular position to the occlusal plane, reinforcing the idea that a patient's occlusion must be clinically watched carefully, and together with other etiological factors of the non-carious cervical lesions (erosion, abrasion and attrition) they can generate structural loss and the characteristic lesions observed [30].

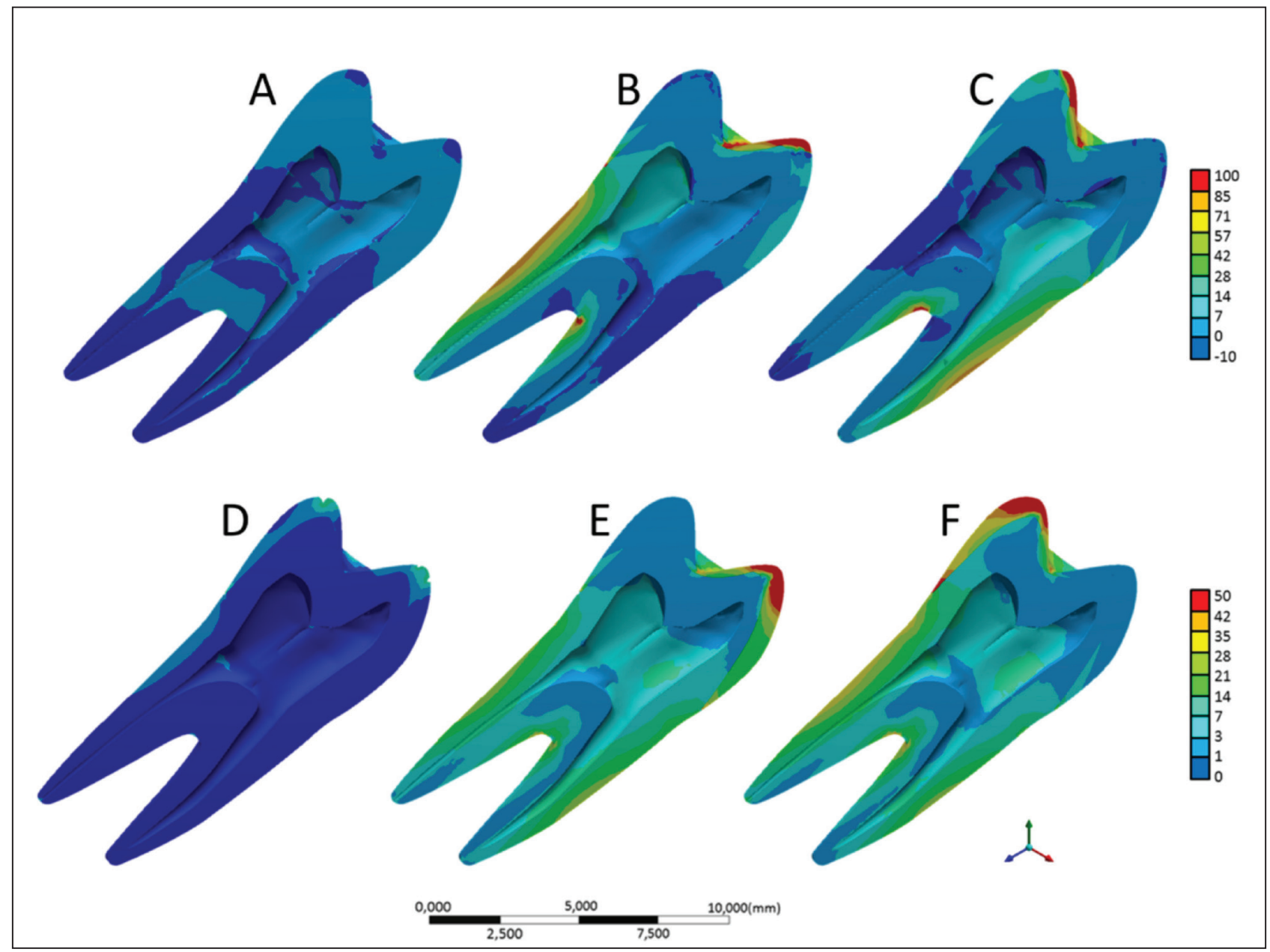

Figure 5 - Sagital view of tensile stress (first row) and shear stress (Second row).A,D) centric occlusion; B,E) Working contact and C,F) Balancing contact 


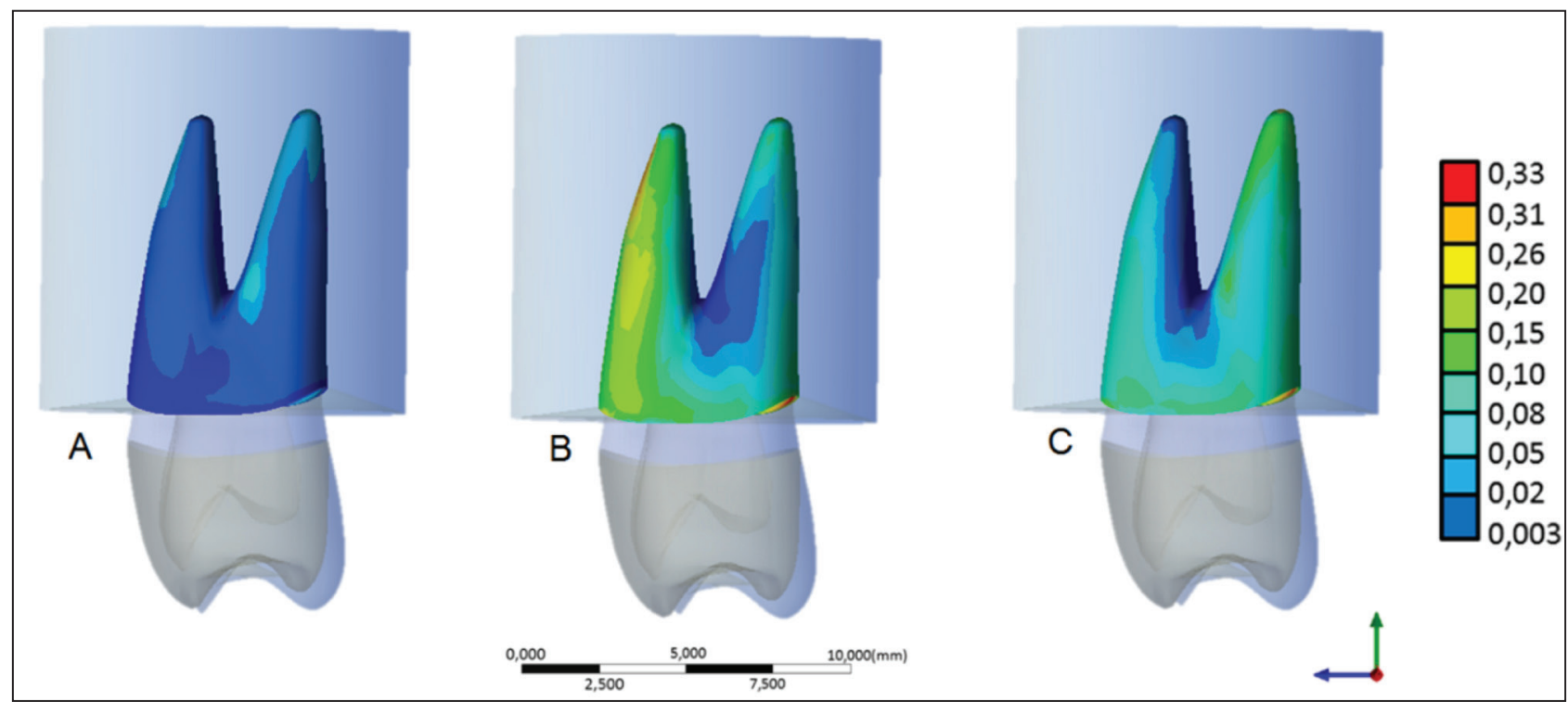

Figure 6 - Equivalent strain on periodontal ligament during occlusion contact in: A) central occlusion; B) work cusp and C) balance cusp

\section{CONCLUSION}

Within the limitations of this study, we can conclude that the stress concentration in a superior premolar is most common when eccentric contacts are exercised. The balancing contacts generate higher tensile and shear stress on the cervical area and must be prevented once observed.

\section{ACKNOWLEDGES}

The authors would like to thank the Foundation for Research Support of the State of São Paulo (FAPESP) for the scholarship, through the process number 2016/20021-0.

\section{REFERENCES}

1. Michael JA, Kaidonis JA, Townsend GC. Non-carious cervical lesions on permanent anterior teeth: a new morphological classification. Aust Dent J. 2010 Jun;55(2):134-7. doi: 10.1111/j.18347819.2010.01228.x.

2. Borges AL, Borges AB, Xavier TA, Bottino MC, Platt JA. Impact of quantity of resin, $C$-factor, and geometry on resin composite polymerization shrinkage stress in Class V restorations. Oper Dent. 2014 Mar-Apr;39(2):144-51. doi: 10.2341/12-440-L. Epub 2013 Jun 20.

3. Khan F, Young WG, Shahabi S, Daley TJ. Dental cervical lesions associated with occlusal erosion and attrition. Aust Dent J. 1999 Sep;44(3):176-86.
4. Grippo J0. Abfractions: a new classification of hard tissue lesions of teeth. J Esthet Dent. 1991 Jan-Feb;3(1):14-9.

5. Bartlett DW, Shah P. A critical review of non-carious cervical (wear) lesions and the role of abfraction, erosion, and abrasion. J Dent Res. 2006 Apr;85(4):306-12.

6. Oginni $\mathrm{AO}$, Olusile $\mathrm{AO}$, Udoye $\mathrm{Cl}$. Non-carious cervical lesions in a Nigerian population: abrasion or abfraction? Int Dent J. 2003 Oct;53(5):275-9.

7. Pegoraro LF, Scolaro JM, Conti PC, Telles D, Pegoraro TA. Noncarious cervical lesions in adults: prevalence and occlusal aspects. J Am Dent Assoc. 2005 Dec;136(12):1694-700.

8. Estafan A, Furnari PC, Goldstein G, Hittelman EL. In vivo correlation of noncarious cervical lesions and occlusal wear. J Prosthet Dent. $2005 \mathrm{Mar} ; 93(3): 221-6$.

9. LittleStar ML, Summitt JB. Non-carious cervical lesions: an evidenced-based approach to their diagnosis. Tex Dent J. 2003 0ct; 120(10):972-80.

10. Costa AK, Xavier TA, Paes-Junior TJ, Andreatta-Filho OD, Borges AL. Influence of occlusal contact area on cusp defection and stress distribution. J Contemp Dent Pract. 2014 Nov 1;15(6):699-704.

11. Tribst JP, Dal Piva AM, Borges AL. Biomechanical tools to study dental implants: A literature review. Braz Dent Sci. 2016;19(4):5-11.

12. Tribst JP, Dal Piva AM, Borges AL. Biomechanical behavior of indirect composite materials: a 3D-FEA study. Braz Dent Sci. 2017;20(3):52-7.

13. Rees JS. The effect of variation in occlusal loading on the development of abfraction lesions: a finite element study. J Oral Rehabil. 2002 Feb;29(2):188-93.

14. Rees JS, Hammadeh M, Jagger DC. Abfraction lesion formation in maxillary incisors, canines and premolars: a finite element study. Eur J Oral Sci. 2003 Apr;111(2):149-54. 
15. Borcic J, Anic I, Smojver I, Catic A, Miletic I, Ribaric SP. 3D finite element model and cervical lesion formation in normal occlusion and in malocclusion. J Oral Rehabil. $2005 \mathrm{Jul} ; 32(7): 504-10$

16. Souza A, Xavier TA, Platt JA, Borges A. Effect of Base and Inlay Restorative Material on the Stress Distribution and Fracture Resistance of Weakened Premolars. Oper Dent. 2015 JulAug;40(4):E158-66. doi: 10.2341/14-229-L.

17. Noritomi PY, Xavier TA, Silva JVL. A comparison between BioCAD and some known methods for finite element model generation. In: Bártolo PJ. Innovative Developments and Physical Prototyping. Boca Raton: CRC Press. 2011. p685-90.

18. Versluis A, Tantbirojn D, Pintado MR, DeLong R, Douglas WH. Residual shrinkage stress distributions in molars after composite restoration Dent Mater. 2004 Jul;20(6):554-64.

19. Rundquist BD, Versluis A. How does canal taper affect root stresses? Int Endod J. 2006 Mar;39(3):226-37.

20. Souza A, Xavier TA, Platt JA, Borges A. Effect of Base and Inlay Restorative Material on the Stress Distribution and Fracture Resistance of Weakened Premolars. Oper Dent. $2015 \mathrm{Jul}-$ Aug;40(4):E158-66. Doi: 10.2341/14-229-L. Epub 2015 Mar 12.

21. Lee WC, Eakle WS. Stress-induced cervical lesions: Review of advances in the past 10 years. J Prosthet Dent. 1996 May;75(5):487-94

22. Tanaka M, Naito T, Yokota M, Kohno M. Finite element analysis of the possible mechanism of cervical lesion formation by occlusal force. J Oral Rehabil. 2003 Jan;30(1):60-7.
23. Abdalla R, Mitchell RJ, Ren YF. Non-carious cervical lesions imaged by focus variation microscopy. J Dent. 2017 Aug;63:14-20. doi: 10.1016/j.jdent.2017.05.001.

24. Telles D, Pegoraro LF, Pereira JC. Incidence of noncarious cervical lesions and their relation to the presence of wear facets. J Esthet Restor Dent. 2006;18(4):178-83; discussion 184.

25. Spears IR, van Noort R, Crompton RH, Cardew GE, Howard IC. The effect of enamel anisotropy on the distribution of stress in a tooth. J Dent Res. 1993 Nov;72(11):1526-31.

26. N S, N M, Shetty A, Kumari A, Dn N. Finite element analysis of stress concentration in Class $V$ restorations of four groups of restorative materials in mandibular premolar. J Conserv Dent. 2008 Jul;11(3):121-6. doi: 10.4103/0972-0707.45251.

27. Green Jl. Prevention and Management of Tooth Wear: The Role of Dental Technology. Prim Dent J. 2016 Aug 1;5(3):30-33.

28. Hemanth M, Deoli S, Raghuveer HP, Rani MS, Hegde C, Vedavathi B. Stress Induced in the Periodontal Ligament under Orthodontic Loading (Part I): A Finite Element Method Study Using Linear Analysis. J Int Oral Health. 2015 Aug;7(8):129-33.

29. Nascimento MM, Dilbone DA Pereira PN, Duarte WR, Geraldeli S, Delgado AJ. Abfraction lesions: etiology, diagnosis, and treatment options. Clin Cosmet Investig Dent. 2016 May 3:8:79-87. doi: 10.2147/CCIDE.S63465. eCollection 2016.

30. Koolstra JH, van Eijden TM, Weijs WA, Naeije M. A threedimensional mathematical model of the human masticatory system predicting maximum possible bite forces. J Biomech. 1988;21(7):563-76.

\section{João Paulo Mendes Tribst}

\section{(Corresponding address)}

PhD Student.

Adress: Av. Eng. Francisco José Longo, no 777 . Jardim São

Dimas, 12245-000 - São José dos Campos/SP, Brasil.

Mailing address: joao.tribst@gmail.com;

Phone: (12) 3947-9032

Date submitted: 2017 0ct 09

Fax: (12) 3947-9010 